\title{
Synthesis of the isofatty acid 13-methyl-tetradecanoic acid and its triglyceride
}

\author{
By S. Zlatanos*, K. Laskaridis, E. Koliokota and A. Sagredos \\ Chemical Engineering Department, Aristotle University of Thessaloniki. 54124 Thessaloniki, Greece \\ ( ${ }^{\star}$ Corresponding author: szlatano@eng.auth.gr)
}

\begin{abstract}
RESUMEN
Síntesis del ácido iso-13-metil-tetradecanoico y sus triglicéridos.

Una nueva y práctica síntesis del ácido graso iso-13-metil-tetradecanoico y sus triglicéridos se describe aquí. Este iso- ácido graso se prepara a través de la elongación de la cadena del ácido undecanoico con isobutiraldehido según Wittig por reacción entre la sal de bromuro de undecanoico etil-éster trifenilfosfonio y metilato sódio seguido de la adición de isobutiraldehido. Su triglicérido está formado por la esterificación del iso ácido graso libre con glicerina sin catalizador. Su pureza es superior al $99 \%$, después de una alta refinación sobre gel de sílice activado. El rendimiento total se estimó en el $22,8 \%$.
\end{abstract}

PALABRAS CLAVE: Ácido 13-metil-tetradecanoico (15:0 iso) - Ácido graso - Iso-13-metil-11cis-tetradecenoico (15:1 iso, $\omega 3 \mathrm{c}$ ) - Iso ácido graso - Triglicéridos del ácido 13-metiltetradecanoico.

\section{SUMMARY}

Synthesis of the isofatty acid 13-methyl-tetradecanoic acid and its triglyceride.

A new and more convenient synthesis of the isofatty acid 13-methyl-tetradecanoic acid and its triglyceride is described here. This isofatty acid is prepared through elongation of the undecanoic acid chain with isobutyraldehyde according to Wittig by the reaction between bromo-undecanoic acid ethyl ester-triphenylphosphonium salt and sodium methoxide followed by the addition of isobutyraldehyde. Its triglyceride is formed by the esterification of the free isofatty acid with glycerin without catalyst. Its purity was over $99 \%$ after high refining over activated silica gel. Total yield was estimated to be $22,8 \%$.

KEY-WORDS: Isofatty acid - 13-methyl-tetradecanoic acid (iso 15:0) - Isofatty acid 13- methyl-11cis-tetradecenoic acid (iso 15:1, $\omega 3$ c) - Triglyceride of 13-methyl-tetradecanoic acid.

\section{INTRODUCTION}

In recent years particular attention has been paid to the synthesis of many fatty acids because of their involvement in cellular functions (Constantinou-
Kokotou V, Kokotos G, 1999). Saturated and unsaturated fatty acids with a main chain length of C12-C24 (Sagredos, von Leitner 1986) are well know constituents of human blood and body lipids and particular phospholipids of cell membrane. A great number of them has been found in the lipids of animals, plants and microorganisms (Bergelson, Shemyakin, 1964).

Many unsaturated fatty acids have been synthesized via the Wittig reaction (Wittig, Geisler, 1953, Schrodger, Berger, 2000). Bergelson and Shemyakin (Bergelson, Shemyakin, 1963, Bergelson et. al., 1963) have reported the synthesis of natural cis-ethylenic acids isolated from various biological sources, such as palmitovaccenic acid (formed by Streptococci), cetoleic acid (a constituent of marine animal fat) and cis-9-hexacosen-9oic acid from the lipids of marine sponges. The synthesis of $6 Z, 9 Z, 12 Z, 15$-hexadecatetraenoic acid (Pohnert et. al., 2004), which has been found in fish oil (Silk, Hahn, 1954), has also been described. 12 - methylpentadecanoic acid is an anteiso fatty acid, which has also been synthesized via the Wittig reaction, and is the dominating anteiso fatty acid in food and bacteria (Thurnhofer, Vetter, 2006). 13-Methyl-tetradecanoic acid is a saturated isofatty acid which is not synthesized in the human body, but occurs naturally in both bovine and human milk, as well as in various ox and sheep depot fats (Klein et. al., 1980). It has been synthesized electolytically (Klein et. al., 1980, Yang Zhenhua, 1998) from isovaleric acid and methyl hydrogen dodecanedioate in a methanolic solution by the Kolbe electrolysis. But, the Kolbe reaction is not suitable for a medium or large scale production since it results in low yields and a lot of by-products. Yang Zhenhua 1998 has also isolated 13-methyltetradecanoic acid by HPLC (High performance liquid chromatography) in minor amounts from products obtained from the fermentation of the bacterial strain, Stenotrophomonas maltophilia assigned ATCC 202105. According to Yang Zhenhua, the saturated and monounsaturated iso and anteisofatty acids and especially the 13-methyl-tetradecanoic acid possess anticancer 
effects (Yang Zhenhua 1998). The 13-methyltetradecanoic acid has been used by Klein et al. as a structurally labelled marker in dietary studies in rats in order to investigate the mobility of fatty acyl chains in adipose tissue (Klein et al., 1980).

The aim of this study was to synthesize the most important of the isofatty acids, the 13-methyltetradecanoic acid (iso 15:0) and its triglyceride, as well as the monounsaturated isofatty acid $15: 1 \omega 3 \mathrm{c}$ in one reaction scheme with a convenient and practical method in medium scale for evaluating it in dietary, biological clinical experiments.

\section{MATERIALS AND METHODS}

\subsection{Materials}

11-bromo-undecanoic acid: Fluka, Buchs, Switzerland

Triphenylphosphine: Fluka, Buchs, Switzerland

Isobutyraldehyde: Fluka, Buchs, Switzerland

Palladium/active carbon: Merck, 10\% Pd, Darmstadt, Germany

\subsection{Procedures}

Step1 : Synthesis of ethyl-11-bromo-undecanoate 1 $4.350 \mathrm{~kg}$ (16.4 mol) 11-bromo-undecanoic acid, $13 \mathrm{~L}$ ethanol, $0.2 \mathrm{~L}$ sulphuric acid were boiled for 16 $\mathrm{h}$ under reflux. Then, ca. $5 \mathrm{~L}$ excess of ethanol were distilled off, the ester was washed with acid free mineral water and dried under a water jet vacuum at $80^{\circ} \mathrm{C}$. Subsequently, the ethyl ester was distilled.

Boiling point of the main fraction: $140-146^{\circ} \mathrm{C}$

Yield: $4.325 \mathrm{~kg}(=89.6 \%)$ ethyl-11-bromoundecanoate 1

Step 2: Synthesis of ethyl -undecanoatetriphenylphosphonium bromide 2

$4.325 \mathrm{~kg}$ (14.7 mol) of ethyl-11-bromo-undecanoate $1,4.627 \mathrm{~kg}$ (17.64 mol) of triphenylphosphine and $5 \mathrm{~L}$ of toluene were heated under nitrogen bubbling without stirring at $90^{\circ} \mathrm{C}$ for $14 \mathrm{~h}$. After cooling overnight at room temperature the reaction mixture was separated into two phases. The upper phase was transferred into a separatory funnel. The viscous lower layer was extracted with $5 \mathrm{~L}$ diethyl ether and the ether extract was added to the separated upper phase. After removing the ether in a rotary evaporator, the residue was stirred at $90^{\circ} \mathrm{C}$ for $8 \mathrm{~h}$. This residue was added to the viscous lower layer and distilled again free from the rest of toluene and diethyl ether. Yield: $7.67 \mathrm{~kg}$ ( $=93.8 \%$ ) ethyl -undecanoate-triphenylphosphonium bromide 2

Step 3: Synthesis of 13-methyl-11-tetradecenoic ethyl ester 4

$7.67 \mathrm{~kg}(13.8 \mathrm{~mol})$ of yliid 2 diluted in $20 \mathrm{~L}$ dimethyl formamide were poured into a $50 \mathrm{~L}$ reaction flask and $596.7 \mathrm{~g}(11 \mathrm{~mol})$ of sodium methoxide were added. The reaction solution was stirred for 1 $\mathrm{h}$ at room temperature, while the solution changed color from red-brown-orange. Then, $598.5 \mathrm{~g}$ (8.3 mol) from fresh distilled isobutyraldehyde were carefully added under cooling $\left(4-8^{\circ} \mathrm{C}\right)$, while stirring for a further $60 \mathrm{~h}$ at room temperature. After adding $10 \mathrm{~L}$ of water the mixture was extracted five times with $5 \mathrm{~L}$ hexane each time. The hexane extracts were combined and washed three times with 10 $\mathrm{L}$ of water each time. After removing hexane at a rotary evaporator at $80^{\circ} \mathrm{C} /$ water jet vacuum, $2.0 \mathrm{~kg}$ of a light brown oil was isolated as a 50:50 mixture of methyl and ethyl esters.

GS-MS analysis (Column: 30 m DB-624 × 0.32 $\mathrm{mm}$ ID $\times 1.8 \mu \mathrm{m}$ film thickness: Temp. program: $50^{\circ} \mathrm{C}, 1 \mathrm{~min}$, rate $10^{\circ} \mathrm{C} / \mathrm{min}, 280^{\circ} \mathrm{C}, 20 \mathrm{~min}$ isotherm; 1 $\mu \mathrm{L}$, split) shows a mixture composed of $50 \%$ ethyl ester and $50 \%$ methyl ester of 13-methyl-tetradecenoic acid;

Ethyl ester: $\mathrm{MS}\left(\mathrm{M}^{+} 268, \mathrm{~m} / \mathrm{z} 223\left(\mathrm{M}^{+}-\mathrm{OC}_{2} \mathrm{H}_{5}\right)\right)$; Methyl ester: $\mathrm{MS}\left(\mathrm{M}^{+} 254, \mathrm{~m} / \mathrm{z} 223\left(\mathrm{M}^{+}-\mathrm{OCH}_{3}\right)\right)$.

Step 4: Saponification of 13-methyl-tetradecenoic acid esters 5 and 6

$1.95 \mathrm{~kg}$ of the ester mixture was dissolved in 8 $\mathrm{L}$ water and $8 \mathrm{~L}$ methanol. Then, a solution of $400 \mathrm{~g}$ (10 mol) sodium hydroxide in $2 \mathrm{~L}$ water was added and the mixture was saponified overnight with continuous bubbling of nitrogen. The saponified solution was extracted three times with $3 \mathrm{~L}$ diethyl ether to remove the unsaponified material and then acidified with $50 \%$ sulphuric acid. The free fatty acid was extracted with diethyl ether and the ether extract was washed with water 3 times to be free from mineral acid. After removing diethyl ether at $80^{\circ} \mathrm{C}$ with a water jet vacuum the free fatty acid was dried and distilled at reduced pressure.

Boiling point of the main fraction: $142-143^{\circ} \mathrm{C} /$ $0.05 / 0.06 \mathrm{hPa}$

Yield of the main fraction: $1190 \mathrm{~g}$ (35.9\% ref. to phosphonium salt) 2

GC analysis of the main fraction (Column: Sil $8850 \mathrm{~m} \times 0.25 \mathrm{~mm}$ ID $\times 0.25 \mu \mathrm{m}$ film thickness: Temp. program: $80^{\circ} \mathrm{C}, 5^{\circ} \mathrm{C} / \mathrm{min}$ to $220^{\circ} \mathrm{C}, 25 \mathrm{~min}$ isotherm ${ }^{\circ} \mathrm{C} ; 3 \mu \mathrm{L}$, split, FID):

The main fraction consists of a mixture from ca. 94\% 13-methyl-11-cis-tetradecenoic acid (Rt. 22.150) and of ca. 6\% 13-methyl-11-trans-tetradecenoic acid (Rt. 21.91).

Acid value (DGF-method C-V. 2): 236 (calc. 233.8)

lodine value (DGF-method C-V. 11d): 104.5 (calc. 105.7)

GC/MS-analysis (Column: 30 m DB-624 × 0.32 $\mathrm{mm}$ ID $\times 1.8 \mu \mathrm{m}$ film thickness: Temp. program: $50^{\circ} \mathrm{C}, 1 \mathrm{~min}$, rate $10^{\circ} \mathrm{C} / \mathrm{min}$ to $280^{\circ} \mathrm{C}, 20 \mathrm{~min}$ isotherm; $1 \mu \mathrm{L}$, split):

The silylo derivative shows an intensive fragment with MS: $297\left(\mathrm{M}^{+}+\mathrm{SiMe}_{2}, \mathrm{M}^{+}=240\right)$. It confirms a calculated $240 \mathrm{~mol}$ weight for the methyltetradecenoic acid 5. acid

Step 5: Hydrogenation of 13-methyl-tetradecenoic

To $1176 \mathrm{~g}$ (4.9 mol) fatty acid 7 diluted in 2.5 $\mathrm{L}$ acetic acid and $118 \mathrm{~g} 10 \% \mathrm{Pd} /$ active carbon were added under a nitrogen atmosphere. After displacing nitrogen with hydrogen the fatty acid 7 was hydrogenated under stirring at $60^{\circ} \mathrm{C}$, while the temperature was increased up to $70^{\circ} \mathrm{C}$. After $4 \mathrm{~h}$ 
$115 \mathrm{~g} \mathrm{10 \%} \mathrm{Pd} /$ active carbon was added again and hydrogen was bubbled for a further $7.5 \mathrm{~h}$ in order to complete the hydrogenation. The catalyst was filtered and washedwith warm acetic acid. After removing acetic acid at $90^{\circ} \mathrm{C}$ in a water jet vacuum the residue of $1175 \mathrm{~g}$ was isolated and distilled.

Boiling point of the main fraction: $165-178^{\circ} \mathrm{C}$ $0.07 \mathrm{hPa}$

Yield of the main fraction: $897 \mathrm{~g}$ of 13-methyltetradecanoic acid $(7$ ) $=75.5 \%$

Yield of the main fraction w.r. to 11-bromoundecanoic acid $=22.8 \%$

GC analysis of the main fraction (Column: Sil $8850 \mathrm{~m} \times 0.25 \mathrm{~mm}$ ID $\times 0.25 \mu \mathrm{m}$ film thickness: Temp. program.: $80^{\circ} \mathrm{C}, 5^{\circ} \mathrm{C}$ a min to $220^{\circ} \mathrm{C}, 25$ min isotherm; $3 \mu \mathrm{L}$, split, FID) shows one main component of $99.6 \%$.

Acid value (DGF-method C-V. 2): 232.7 (theory 231.8)

lodine value (DGF-method C-V. 11d): 0.0 (theory 0.0)

Step 6: Esterification of 13-methyl-tetradecanoic acid ( 8 ) to triglyceride 9

$786 \mathrm{~g}(3.25 \mathrm{~mol})$ of 13-methyl-tetradecanoic

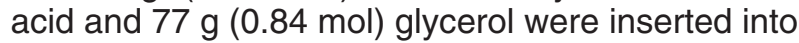
a $2 \mathrm{~L}$ reaction round flask, which was fitted with a thermometer, condensing glass apparatus and heating jacket under control. The esterification was carried out at $180^{\circ} \mathrm{C} / 5 \times 10^{-2} \mathrm{hP}$ vacuum and took 26 $\mathrm{h}$. During the esterification the reaction water was removed off to a total amount of $51 \mathrm{~g}$ (theory: 45 $\mathrm{g}=2.5 \mathrm{~mol}$ water). The esterification was finished after $26 \mathrm{~h}$, as no further reaction water was formed.
The excess (180 g) of 13-methyl-tetradecanoic acid was distilled off at $152-160^{\circ} \mathrm{C} 0.1 \mathrm{hPa}$.

Yield of crude triglyceride: $633 \mathrm{~g}(0.83 \mathrm{~mol})$

Acid value (DGF-method C-V 2): 3.2

The crude triglyceride was highly refined over activated silica gel according to the process reported highly refining of edible triglycerides (Sagredos, 1986, Sommermeyer et. al., 1998).

$630 \mathrm{~g}$ of crude triglyceride were diluted with 1.25 $\mathrm{L}$ hexane and placed over a $300 \mathrm{~g}$ silica gel column, which was eluted with hexane. Then, the silica gel column was additionaly eluted with $1.25 \mathrm{~L}$ hexane. After gently removing the hexane (Sagredos, 1986, Sommermeyer et. al., 1998) the highly refined triglyceride was isolated.

Yield: 505 g (79.7\% w.r. to glycerol) (Figure 1).

Analytical data:

Thin layer chromatography (petroleum ether : ether : acetic acid $70: 30: 2$ ( $\mathrm{v}: \mathrm{v}: \mathrm{v})$; molybdatophosphoric acid; $\left.160^{\circ} \mathrm{C}\right)$ : one spot at $\mathrm{Rt}=0.66$.

GC analysis after esterification to methyl ester (Column: Sil $8850 \mathrm{~m} \times 0.25 \mathrm{~mm}$ ID $\times 0.25 \mu \mathrm{m}$ film thickness: Temp. program: $60^{\circ} \mathrm{C}, 5^{\circ} \mathrm{C} / \mathrm{min}$ up to $220^{\circ} \mathrm{C}, 25 \mathrm{~min}$ isotherm; $3 \mu \mathrm{L}$, split at $250^{\circ} \mathrm{C}$, FID at $\left.300^{\circ} \mathrm{C}\right)$ : one component $(99.1 \%)$ at Rt 28.07 .

GPC analysis was carried out according to the method (Unbehend et. al., 1973) (columns: SVD 1: 5 $\mu \mathrm{m}, 50 \mathrm{~A}$; sample concentration $3.00 \mathrm{~g} / \mathrm{L}$; injection vol. $40 \mu \mathrm{L}$; eluent THF; similar to the method (Unbehend et. al., 1973): Main component (99.7\%) a monomer triglyceride from about 750 mol. weight and traces of a dimeric triglyceride from about 1550 molecular weight, a diglyceride from about 500 molecular weight and free fatty acid from ca. 180 molecular weight (Figure 1).

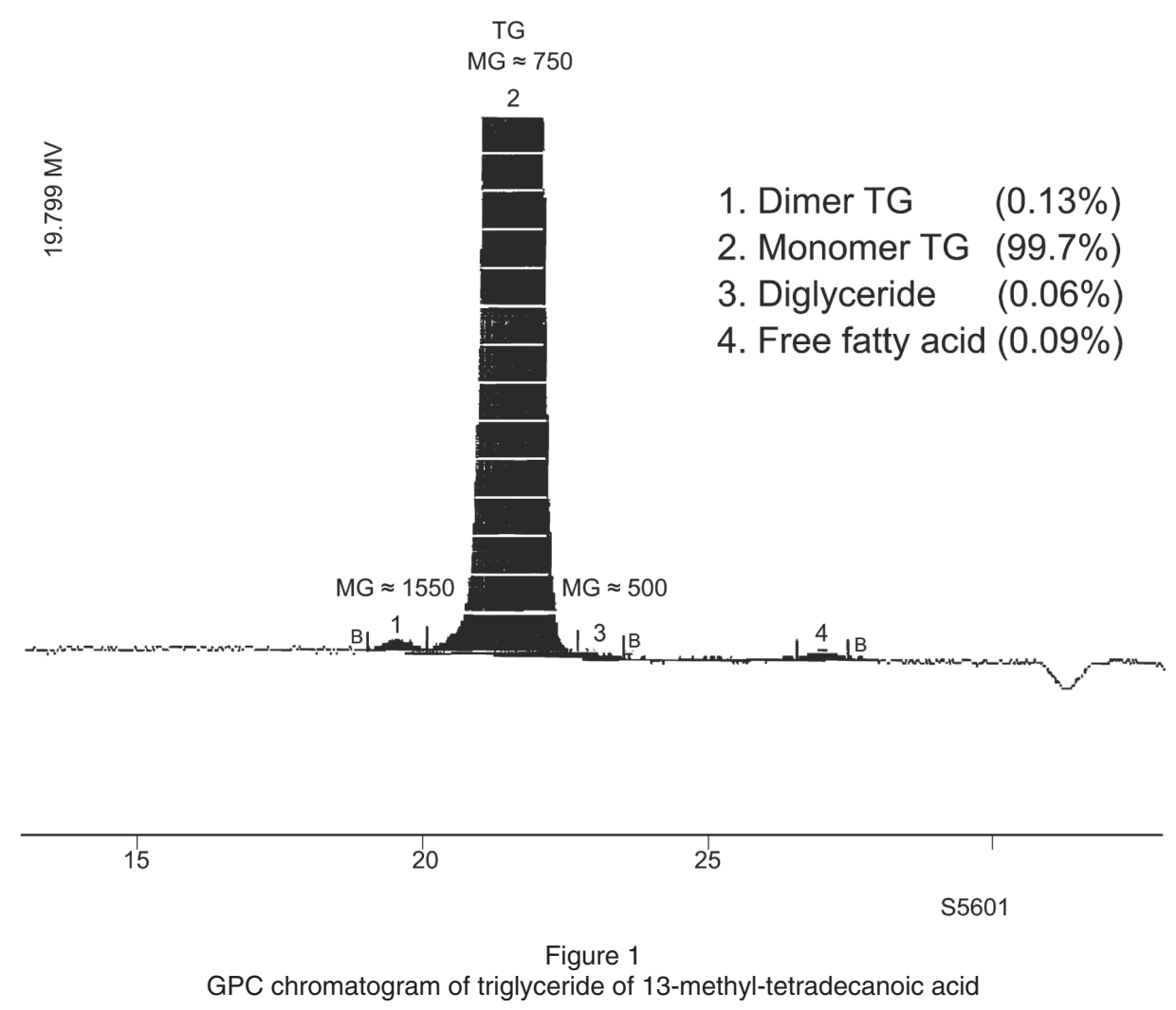


The estimation of the molecular weight is calculated according to a parabolic measurement curve of glycerides (mol. weight of triglyceride theoretically estimated 764).

\section{RESULTS AND DISCUSSION}

The isofatty 13-methyl-tetradecanoic acid is synthesized in a five-step process according to Figure 2.

In the first step, 11-bromo-undecanoic acid was esterified with ethanol in the presence of sulphuric acid as catalyst to ethyl-11-bromo-undecanoate 1 .

In the second step ethyl-undecanoate triphenylphosphonium bromide 2 was formed from ethyl-11-bromo-undecanoate 1 and triphenylphosphine in a toluene solution.

In the third step the phosphonium salt 2 was dissolved in dimethyl formamide and processed with sodium methoxide. Then, isobutyraldehyde was added and the mixture reached room temperature according to the Wittig reaction under elongation of undecanoic ethyl ester chain to a mixture from about $50 \%$ ethyl ester and $50 \%$ methyl ester of 13-methyl-11-tetradecenoic acid. The methyl ester was formed from the methanol produced during the previous step through the transterification of the undecanoic ethyl ester.

In the fourth step, the ester mixture was gently saponified with sodium hydroxide in an aqueous methanolic solution overnight at room temperature. The formed fatty acid sodium salt was acidified with sulphuric acid to free monounsaturated isofatty acid 13-methyl-11-tetradecenoic acid (iso 15:1 $\omega 3 \mathrm{c}$ ) in a yield of about $36 \%$. The free fatty acid consisted of about 94\% 13-methyl-11-cis-tetradecenoic acid and about 6\% 13-methyl-11-trans-tetradecenoic acid according to a gas chromatographic analysis. The cis/trans isomer proportion was in accordance with the Wittig reaction of a phosphonium salt with an aldehyde in the presence of a solvent like dimethyl formamide.

In the next reaction ( $5^{\text {th }}$ step) the 13-methylcis/trans-11-tetradecenoic acid was hydrogenated to 13-methyl-tetradecanoic acid 8 by adding 10\% $\mathrm{Pb}$ on activated carbon as catalyst under bubbling

1) $\mathrm{Br}-\left(\mathrm{CH}_{2}\right)_{10}-\mathrm{COOH}+\mathrm{H}_{3} \mathrm{C}-\mathrm{CH}_{2} \mathrm{OH} \stackrel{\mathrm{H}^{\oplus}}{\longrightarrow} \mathrm{Br}\left(\mathrm{CH}_{2}\right)_{10} \mathrm{COO}-\mathrm{C}_{2} \mathrm{H}_{5}$

2) (1) $+\left(\mathrm{C}_{6} \mathrm{H}_{5}\right)_{3} \mathrm{P} \longrightarrow\left[\left(\mathrm{C}_{6} \mathrm{H}_{5}\right)_{3} \stackrel{+}{\mathrm{P}}-\mathrm{CH}_{2}-\left(\mathrm{CH}_{2}\right)_{9}-\mathrm{COO}-\mathrm{C}_{2} \mathrm{H}_{5}\right] \mathrm{Br}-$ (2)

3) (2) $+\mathrm{CH}_{3} \mathrm{ONa} \longrightarrow \mathrm{Ph}_{3} \mathrm{P}=\mathrm{CH}\left(\mathrm{CH}_{2}\right)_{9} \mathrm{COOC}_{2} \mathrm{H}_{5}$ (3) $+\mathrm{Ph}_{3} \mathrm{P}=\mathrm{CH}\left(\mathrm{CH}_{2}\right)_{9} \mathrm{COOCH}_{3}$

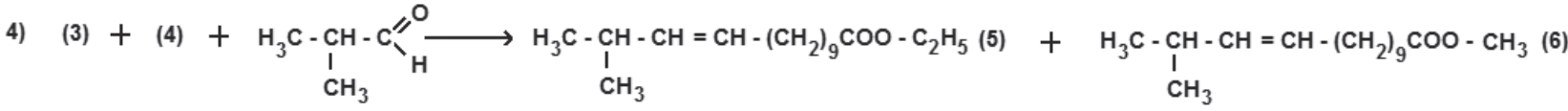

5) (5) + (6) $\frac{1 .+\mathrm{NaOH}}{2 .+\mathrm{H}_{2} \mathrm{SO}_{4}} \underset{\substack{\mathrm{C}}}{\longrightarrow} \underset{3}{\mathrm{H}} \mathrm{C}-\mathrm{CH}=\mathrm{CH}-\left(\mathrm{CH}_{2}\right)_{9}-\mathrm{COOH}$

6)

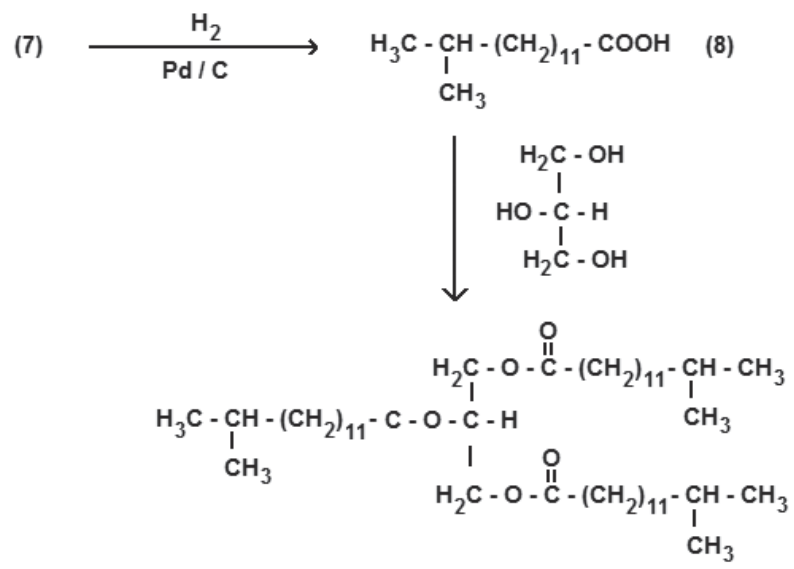


hydrogen at $60^{\circ} \mathrm{C}$. The free fatty acid 8 was purified through vacuum distillation (boiling point $165-178^{\circ} \mathrm{C}$ / $0.07 \mathrm{hPa}$ ) to a purity of about $99.6 \%$.

The esterification of 13-methyl-tetradecanoic acid with glycerol to the corresponding triglyceride was carried out without a catalyst at a temperature of about $180^{\circ} \mathrm{C} 5 \times 10^{-2} \mathrm{hP}$. For successful esterification, a fourfold excess of the free fatty acid 8 was needed in comparison to glycerol. After distilling off the fatty acid excess, the crude triglyceride was highly refined over activated silica gel according to the process described for highly refining of edible triglycerides (Sagredos, 1986, Sommermeyer et. al., 1998).

The refined triglyceride of 13-methyl-tetradecanoic acid 9 shows a purity of about $99.7 \%$ according to gel permeation chromatography (Figure 2).

The yield of this method is twice those obtained by Klein et al. (1980) or by Yang Zhenhua (1998) according to the Kolbe reaction.

\section{CONCLUSIONS}

A new process for the preparation of the 13-methyl-tetradecanoic acid (iso 15:0) and its triglyceride and the monounsaturated isofatty acid

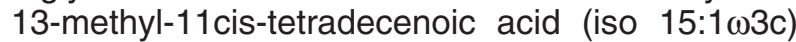
from commercially available raw materials and reagents is described here. The synthesis runs in five steps, including the Wittig reaction, give intermediate and final products of high purity and relatively good yields.

\section{REFERENCES}

Bergelson LD, Schemjakin MM 1964 Synthesis of Naturally Occurring Unsaturated Fatty Acids by Sterically Controlled Carbonyl Olefination. Chem. Intl. Ed. Engl. 3, 250-260.

Bergelson LD, Shemyakin MM 1963 Control of the Steric Course of the Wittig Reaction, Stereochemical Studies and Synthetic Applications. Tetrahedron 19, 149-159.

Bergelson LD. Vaver VA, Barsukov LI, Shemyakin MM 1963 Unsaturated Acids and Macrocyclic Lactones,
Communication 11. Total Synthesis of cis-8Hexadecenoic, cis-11-Hexadecenoic (Palmitovaccenic), cis-7-Octadecenoic, and cis-9-Hexacosenoic Acids. Institute for the Chemistry of Natural Products, Academy of Sciences, USSR, 8, 1417-1421,

Constantinou-Kokotou V, Kokotos G 1999 Synthesis of optically active lipidic a-amino acids and lipidic 2-amino alcohols. Amino Acids 16, 273-285.

DGF-Einheitsmethoden, Methode: $C-V-11 d-(02)$. lodine value according to Wijs. DGF standard methods, 2006.

DGF-Einheitsmethoden, Methode: C-V-2-(06). Determination of acid value and free fatty acid content (acidity). DGF standard methods, 2006.

Klein RA, Halliday D, Pittet PG 1980 The use of 13-Methyltetradecanoic Acid As an Indicator of Adipose Tissue Turnover. Lipids 15, 572-579.

Pohnert G, Adolph S, Wichard T 2004 Short synthesis of labeled and unlabeled 6Z,9Z,12Z,15-hexadecatetraenoic acid as metabolic probes for biosynthetic studies on diatoms. Chemistry and Physics of Lipids 131, 159-166.

Sagredos A.N., Inventor, DE Patent 3643848 C2 1986 Verfahren zur Herstellung hochraffinierter essbarer Glyceridöle mit einem Anteil an ungesättigten Fettsäuren im Triglyceridverband und ihre Verwendung, Proprietor: Natec Institut, Hamburg(DE),

Schroder U, Berger S 2000 The Wittig Reaction with Pyridylphosphoranes. Eur. J. Org. Chem. 2601-2604.

Silk MH, Hahn HH 1954 The isolation and structure of a hexadecatetraenoic acid from South African Pichard oil. Biochem. J. 57, 582-587.

Sommermeyer K, Weidler B, Sagredos A.N., Remse K., Inventors, EU Patent 0298293 B1, 1998, Fettemulsion, Verfahren zu ihrer Herstellung und ihre Anwendung, Proprietor: Fresenius AG, Oberursel(DE),

Thurnhofer S, Vetter W 2006 Synthesis of $(S)$ - (+) enantiomers of food relavant $(n-5)$ monoenoic and saturated an teiso - fatty acids by a Wittig reaction. Tetrahedron 63, 1140-1145.

Unbehend M, Scharmann H, Strauss HJ, Billek G 1973 Anwendung der Gelpermeationschromatographie auf die Untersuchung thermisch-oxydativ. Fette Seifen Anstrichmittel 75, 689-696.

Wittig G, Geisler G 1953 Liebigs Ann. Chem. 580, 44-57.

Yang Zhenhua, inventor US Patent 6,214,875b, 1998, Anticancer effects of specific branched-chain fatty acids and related production process, West Covina, CA (USA). 